\title{
Geochemical aspects of the soil-plant-animal relationship in the development of trace element deficiency and excess
}

\section{By Iain Thornton and Brian J. Alloway, Applied Geochemistry Research Group, Imperial College of Science and Technology, London $S W_{7}$}

It is well recognized that the trace element content of soils and associated grassland or forage may, under certain conditions of farming practice, influence the health of livestock and the economics of agricultural production. There is also evidence, though mainly empirical, that disease in man may at times be related to the trace metal status of the environment in which he lives.

The prime source of trace elements in soils is the parent material from which they are derived. In the UK this is largely weathered bedrock or transported overburden of relatively local origin. The soils developed from these materials tend to reflect their chemical composition. Thus soils developed from acid igneous rocks, such as rhyolites and granites, and from coarse-grained arenaceous rocks, usually contain smaller amounts of the nutritionally essential trace elements than those developed from basic igneous rocks and fine-grained sediments. Trace element deficiencies in grazing livestock, particularly of copper and cobalt, are frequently reported on the former soils, while problems due to excess are sometimes found on the latter. This relationship between animal health and bedrock geochemistry does not apply in those parts of the world where appreciable areas of soils have been developed from wind-borne, water-borne or laterized materials or from old weathered surfaces bearing little compositional relationship to the underlying rock. Similarly, in parts of the more advanced countries, the trace metal content of soils and plants may be considerably enhanced by contamination from urban (Purvis, 1972) and industrial sources, including past and present-day metalliferous mining (Alloway \& Davies, 1971; Thornton, 1974a).

Examples of trace element problems in animals related to the composition of soils or plants or both are numerous and worldwide (Russell \& Duncan, $195^{6}$; Underwood, I97I) and it is not the purpose of this paper to review them. A typical example is the problem of molybdenosis or 'teartness' in cattle initially recognized in an area of some 8100 ha in southw west England and attributed to excess molybdenum in soils and pastures, with concentrations of $15->100 \mu \mathrm{g} \mathrm{Mo} / \mathrm{g}$ in 'teart' compared with $3-5 \mu \mathrm{g} / \mathrm{g}$ in healthy pastures (Ferguson, Lewis \& Watson, 1943; Lewis, 1943). The source of the Mo was ascribed to the clay component of the Lower Lias formation, and calcareous soils derived from this material containing $20 \mu \mathrm{g} \mathrm{Mo} / \mathrm{g}$ or more were described as potentially 'teart' and similar soils with only 2-3 $\mu \mathrm{g} / \mathrm{g}$ as 'non-teart' (Lewis, 1943). Later geological studies showed 
that high concentrations of Mo were only found in the lower zones of the Lower Lias (Le Riche, 1959). Only where soils were developed from these zones were animals affected. Similar animal problems related to excess Mo in the parent material-soil-plant system have been described in Ireland (Walsh, Neenan \& O'Moore, 1952), in the United States (Dye \& O'Hara, 1959; Kubota \& Allaway, 1972) and in mineralized biogeochemical provinces in Armenia (Kovalsky \& Yarovaya, I966).

Trace element deficiencies with a geochemical origin include Co 'pine' in sheep grazing pastures of low Co status on soils developed from granite in south-west England (Patterson, 1938), a similar deficiency in sheep on soils developed from Table Mountain Sandstone in South Africa (Van der Merwe, 1959), and in cattle, sheep and goats on soils derived from granitic drift from the White Mountains in New England (Kubota, I 964). Coast disease, a deficiency of both $\mathrm{Cu}$ and $\mathrm{Co}$ in sheep, has been related to low concentrations of both elements in soils and herbage on calcareous sands in South Australia (Russell \& Duncan, 1956); again a combined deficiency of $\mathrm{Cu}$ and zinc in cattle is associated with low pasture contents on sandy soils in Norway (Havre, 1970).

\section{Factors influencing the rock-soil-plant-animal relationship}

Where residual soils are developed in situ from the underlying strata, animal problems may coincide with a particular rock type as on the granite in south-west England. On the other hand, where parent materials have been mixed and redistributed by alluvial transport or by glacial activity, the trace element composition of the underlying rock may be completely masked by transported overburden or, where drift is of local origin, its effect smeared in the direction of ice movement. Induced $\mathrm{Cu}$ deficiency in cattle, for instance, associated with Mo-rich soil and herbage, has been reported on glacial till containing appreciable amounts of molybdeniferous black shale transported some $2-3 \mathrm{~km}$ from the Bowland Shale outcrop in northern England (Thomson, Thornton \& Webb, 1972).

Soil-forming or pedogenetic processes may lead to the mobilization and redistribution of trace elements both within the soil profile and between neighbouring soil types, thus modifying the influence of parent material on both the total content and the form of trace elements in the soil (Swaine \& Mitchell, 1960; Mitchell, 1965). The extent to which the parent material-topsoil relationship is affected depends both on the age of the soil and the ease of weathering of the primary minerals. In the relatively young soils over much of the UK the parent material remains the dominant factor in determining the soil trace element status. Gleying, leaching, podzolization and surface organic matter accumulation, together with $\mathrm{pH}$ and redox potential, may affect the distribution, form and mobility of trace elements in the soil and their availability to plants. For example, the solubility and thus availability of many trace elements increases in poorly drained soils, while manganese and Co availability decreases and that of Mo increases with rising soil $\mathrm{pH}$. In this context Alderman ( 1968 ) ascribed the higher percentage of herbage and hay samples of low Mn content in south-east England, compared with south Wales, to the predominance of soils of 
higher $\mathrm{pH}$ developed on chalk and Oolitic limestone in the former area. Soil and other factors affecting the soil-plant relationship such as plant species, stage of growth, time of year and lime and fertilizer application have been discussed in detail by Fleming (1965) and Archer (197I). In particular legumes tend to take up larger amounts of trace elements than grasses, and their relative proportion in the sward may markedly influence the dietary intake of grazing stock.

The relationship between trace elements in plants and amounts absorbed and utilized by the animal is again complex and depends on such factors as selectivity in grazing, the degree of dependence of the animal on grass as a source of trace element dietary intake, digestibility of the diet and form and 'availability' of the ingested trace elements.

In view of the complex relationships at each stage of the rock-soil-plant-animal system it is perhaps surprising how frequently trace element deficiencies and toxicities in animals do reflect the composition of the soil and parent material. In recent years there has been a growing awareness not only of clinical, easily recognized disorders but of subclinical or latent situations where marginal imbalance may result in less obvious problems such as unthriftiness, sub-fertility and lowered production, which because of their more widespread occurrence may be of far greater economic significance. With this awareness comes the need for trace element maps to focus attention on the possible suspect areas.

\section{Regional trace element maps and geochemical surveys}

Appreciable progress has been made over the past decade in the mapping of trace element distribution on a regional and national scale. In general, maps have been based on the systematic sampling and analysis of stream sediments, rocks, parent materials, soils or plants, and have been applied to studies on the distribution of plant and animal nutritional disorders and to problems of human health.

Maps have been compiled from soil or plant analysis, or both, in New Zealand (Department of Scientific and Industrial Research, 1967), parts of the United States (Kubota \& Allaway, I972) and Ireland (Brogan, Fleming \& Byrne, 1973) based on the careful selection of relatively few sampling locations and a considerable degree of geographical extrapolation. Similarly rocks, soils, natural vegetation and farm crops have been analysed as part of a systematic wide-scale geochemical survey of the State of Missouri (US Geological Survey, 1969-73). Multi-purpose surveys of trace elements in rocks, soil and vegetation have resulted in the mapping of biogeochemical zones and provinces in the USSR (Kovalsky, 1970), where the programme has been conducted at two levels of sampling intensity: first, at a general reconnaissance level based on only a few samples for each region, and secondly, at a detailed level in specific provinces selected either because of recognized disease in plants, animals or man, or because of characteristic high or low levels of an element or group of elements observed in the general reconnaissance.

Geochemical reconnaissance surveys based on the multi-element analysis of stream sediment samples have been used in the UK and Ireland to delineate areas of potential trace element deficiency or excess (Webb, 1964; Webb \& Atkinson, 1965; Kiely \& 
Fleming, 1969; Thornton \& Webb, 1970). This rapid, low-cost technique is based on the concept that stream sediment represents a composite sample of the erosion products of rock, overburden and soil. Geochemical maps showing the distribution of some twenty elements have recently been prepared for England and Wales and

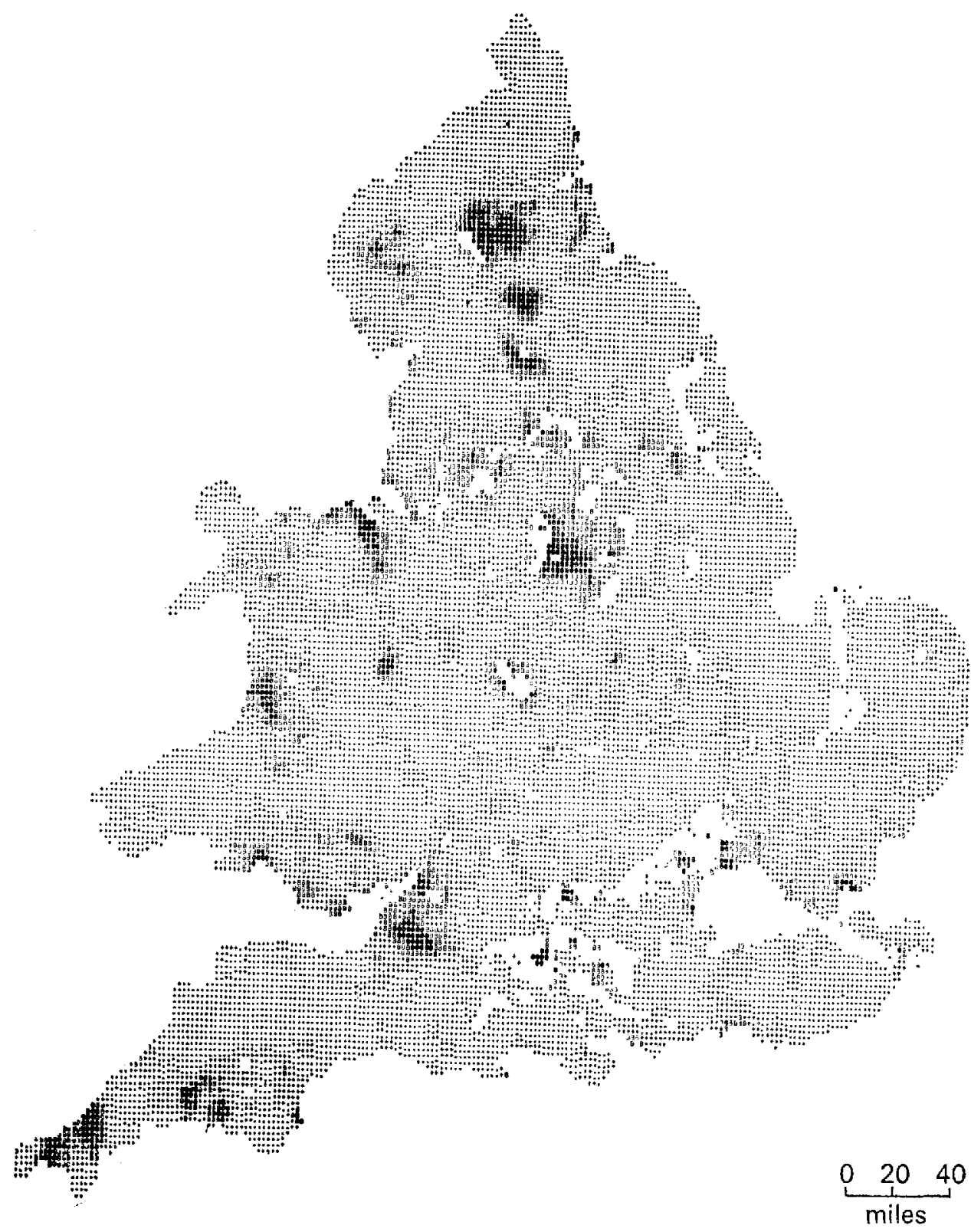

Fig. I. Provisional map showing the distribution of lead in stream sediment in England and Wales, based on a modification of the grey-scale mapping programme described by Howarth ( $97 \mathrm{I}$ ). [ $\mathrm{I}$, Less than $40 \mu \mathrm{g} \mathrm{Pb} / \mathrm{g}$; [t: $\mu \mathrm{g} \mathrm{Pb} / \mathrm{g}$. 
Northern Ireland by the Applied Geochemistry Research Group (Thornton \& Webb, 1973; Webb, Lowenstein, Howarth, Nichol\& Foster, 1973) and provide a catalogue of multi-element data showing the distribution both of several nutritionally essential elements and of potentially toxic 'pollutant' metals such as lead (Fig. 1) and cadmium. As well as reflecting the natural composition of bedrock, parent material and soil, they at the same time provide evidence of regional metal contamination of agricultural land due to past and present-day industrial activity. Such maps are naturally no substitute for soil and herbage analysis where information is required on the farm or field level. They do, however, focus attention on particular areas of concern wherein more detailed, costly and time-consuming surveys by soil, nutrition and veterinary scientists may then be concentrated.

Applications of geochemical reconnaissance maps to studies on the soil-plantanimal relationship have proved encouraging and are illustrated by the following three examples from current investigations.

\section{Mo excess in relation to hypocuprosis in ruminants}

Geochemical surveys in the UK have shown anomalous patterns of Mo in areas underlain by marine black shale facies varying in age from Cambrian to Recent (Thomson et al. 1972). Studies in areas selected from reconnaissance data have clearly shown a significant relationship between high levels of the element in rock, stream sediment, soil and pasture, sometimes associated with clinical signs of $\mathrm{Cu}$ deficiency in cattle (Thomson et al. 1972; Webb, Thornton \& Fletcher, 1968). Further investigations have indicated widespread sub-clinical hypocuprosis in one such area and a marked response in live-weight gain to $\mathrm{Cu}$ supplementation (Thornton, Kershaw \& Davies, 1972a,b). The geochemical reconnaissance map for England and Wales confirms the extensive nature of suspect high-Mo areas, which are thought to exceed 400000 ha and to be of considerable economic significance.

Observations on the distribution of swayback in sheep have recently indicated that this disease is also frequently associated with land falling within these geochemically

Table I. Molybdenum and copper content of topsoils (total) and winter herbage from 'swayback' and 'control' farms, in relation to the regional metal distribution pattern shown by stream sediment analysis

(Ranges and mean values; no. of samples in parentheses)

\begin{tabular}{|c|c|c|c|c|c|c|c|}
\hline \multirow[b]{2}{*}{ 'Swayback' farms } & \multicolumn{2}{|c|}{$\begin{array}{l}\text { Stream sediment } \\
(\mu \mathrm{g} / \mathrm{g})\end{array}$} & \multicolumn{2}{|c|}{ Soil $(\mu \mathrm{g} / \mathrm{g})$} & \multicolumn{3}{|c|}{ Herbage $(\mu \mathrm{g} / \mathrm{g}$ dry matter) } \\
\hline & Mo & $\mathrm{Cu}$ & Mo & $\mathrm{Cu}$ & Mo & $\mathrm{Cu}$ & $\begin{array}{l}\text { Ratio, } \\
\text { Cu:Mo }\end{array}$ \\
\hline Somerset & $15-25$ & $25-50$ & $\begin{array}{l}2-32 \\
16(18)\end{array}$ & $\begin{array}{c}25-63 \\
37(18)\end{array}$ & $\begin{array}{l}2-15 \\
6(18)\end{array}$ & $\begin{array}{c}3-21 \\
12(18)\end{array}$ & $\begin{array}{l}0 \cdot 6-5.6 \\
2 \cdot 7(18)\end{array}$ \\
\hline $\begin{array}{l}\text { Northamptonshire } \\
\text { 'Control' farms }\end{array}$ & $2-3$ & $10-25$ & $\begin{array}{c}2-3 \\
2(43)\end{array}$ & $\begin{array}{c}7-32 \\
20(43)\end{array}$ & $\begin{array}{c}I-4 \\
2(45)\end{array}$ & $\begin{array}{l}5^{-10} \\
8(45)\end{array}$ & $\begin{array}{l}I \cdot 6-9 \cdot 2 \\
4 \cdot 6(45)\end{array}$ \\
\hline $\begin{array}{l}\text { South-east } \\
\text { Northamptonshire }\end{array}$ & $<2$ & $5^{-25}$ & $\begin{array}{l}0.5^{-1} \\
<1(7)\end{array}$ & $\begin{array}{l}22-24 \\
24(7)\end{array}$ & $\begin{array}{l}I-2 \\
I(6)\end{array}$ & $\begin{array}{l}7-14 \\
9(6)\end{array}$ & $\begin{array}{l}5 \cdot 8-15 \cdot 4 \\
8 \cdot 8(6)\end{array}$ \\
\hline
\end{tabular}


defined high-Mo areas. Studies in Somerset and Northamptonshire have confirmed the presence of soils containing more $\mathrm{Mo}$, and an associated lower $\mathrm{Cu}$ :Mo ratio in the dry matter of winter herbage, on 'swayback' compared to 'control' farms (Table I). Together with similar results in the other study-areas (Alloway, r973), these results suggest that the natural distribution of Mo in soils and plants may well play a contributory role in the aetiology of swayback under farm conditions.

\section{Multi-element deficiencies}

The examination of multi-element geochemical information has led to the delineation of several areas, principally underlain by acid igneous rocks and arenaceous deposits, where both soils and pasture contain lower concentrations of one or more of the nutritionally essential elements $\mathrm{Cu}, \mathrm{Co}$ and $\mathrm{Zn}$ (and sometimes $\mathrm{Mn}$ ) than those developed from other types of rock and overburden. For instance, soils and herbage are seen to reflect the low patterns in the stream sediment on sands in East Anglia, the Lower Greensand formation in Sussex, and Permian and Triassic sandstones in Cumberland, which have been compared with some areas of apparent trace element sufficiency in Table 2. The Mn content of soil and herbage in these areas is far more variable, as both the distribution and availability of this element are markedly influenced by local soil factors including drainage and $\mathrm{pH}$. Further similar multi-element low patterns have been observed on granitic rocks in south-west England, on the Bagshot Beds in Dorset and in other areas of sandy soils. In addition, low patterns are also outlined in some of these regions for the 'newer' essential

Table 2. Copper, cobalt and zinc content of topsoil (0-150 mm) and herbage in England, in relation to the regional metal distribution pattern shown by stream sediment analysis

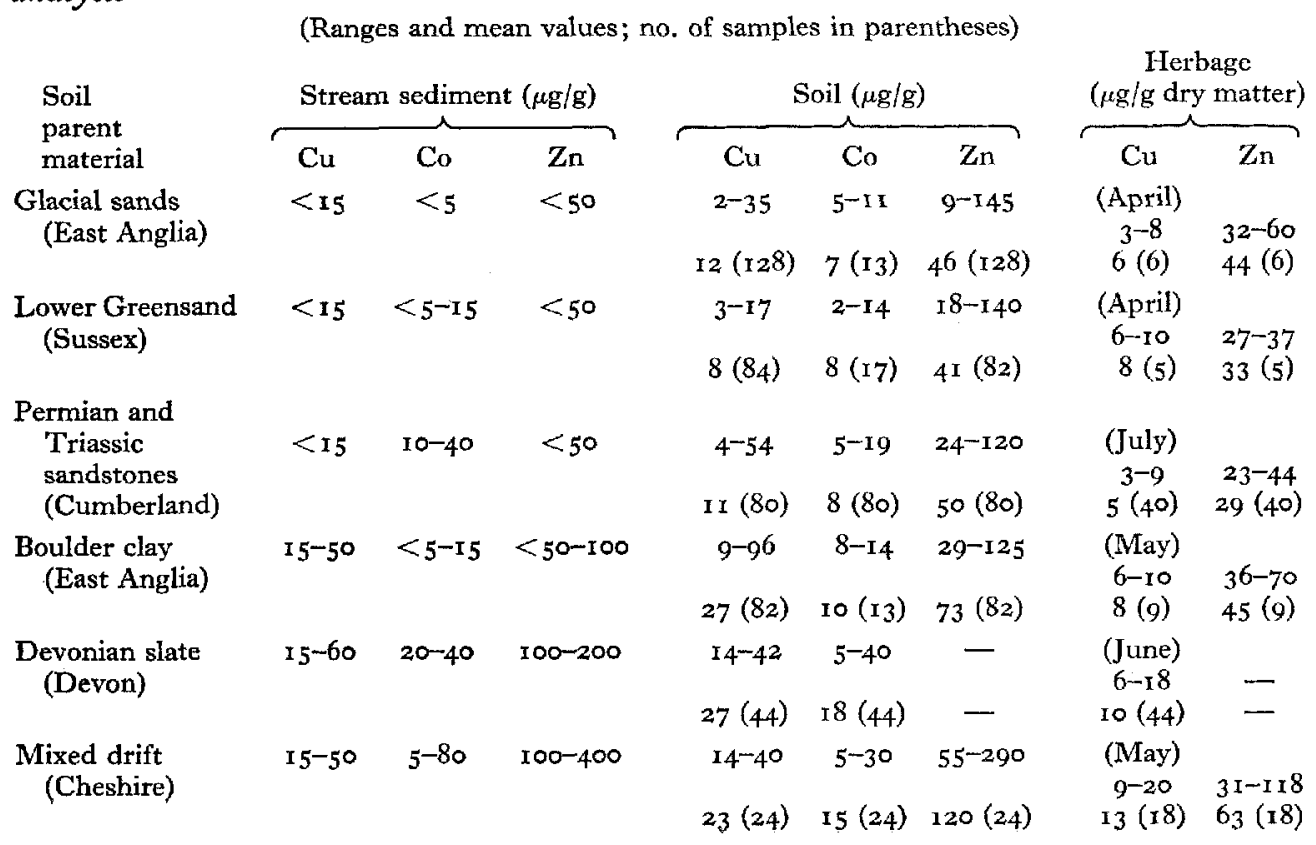


elements chromium, nickel and vanadium. Livestock problems ascribed to the deficiency of either $\mathrm{Cu}$ or $\mathrm{Co}$ have been reported in most of these areas, and a combined deficiency of both $\mathrm{Co}_{0}$ and $\mathrm{Cu}$ is suspected by veterinary practitioners on soils developed on the Old Red Sandstone formation in south Wales. It is suggested that problems may well be in part due to a deficiency of more than one element in further areas of the UK, and more detailed studies are now required on the levels of trace elements in soil, plant and animal tissue together with carefully conducted supplementation experiments on grazing cattle and sheep.

\section{Contamination from metalliferous mining and smelting}

The geochemical maps of England and Wales also provide evidence of contamination on a regional scale with one or more of the elements $\mathrm{Cu}, \mathrm{Pb}, \mathrm{Zn}, \mathrm{Cd}$, tin and arsenic. The map showing the distribution of $\mathrm{Pb}$ (Fig. I) highlights mineralized districts in south-west, central and northern England, and central and north Wales where appreciable areas of agricultural soil have been affected by past mining and smelting activities, some of which date back to Roman times.

Soil studies in the southern Pennines and in the vicinity of the Tamar Valley in south-west England have shown that within any one area the degree of contamination may vary appreciably between individual sites, though soils frequently contain more than ten times the amount of metal present in nearby control or 'background' areas (P. Colbourne, unpublished results). Soils in the Pennine region are considerably enriched in $\mathrm{Pb}$, with values at times exceeding $10 \mathrm{mg} / \mathrm{g}$ in the topsoil. Both alluvial and upland sites in the Tamar area are contaminated with $\mathrm{Cu}, \mathrm{Pb}, \mathrm{Zn}$ and $\mathrm{As}$ (together with $\mathrm{Sn}$ ). On the other hand, in both areas, pasture samples reflect this

Table 3. Copper, lead and zinc content of topsoil $(0-150 \mathrm{~mm})$ and herbage in the south Pennine and Tamar areas of England

(Ranges and mean values; no. of samples in parentheses)

\begin{tabular}{|c|c|c|c|c|c|c|c|}
\hline \multirow{4}{*}{$\begin{array}{l}\text { Area } \\
\text { South Pcnnines } \\
\text { Metal-contaminated } \\
\text { area }\end{array}$} & \multicolumn{3}{|c|}{ Soil $(\mu \mathrm{g} / \mathrm{g})$} & & \multicolumn{3}{|c|}{ Herbage ( $\mu \mathrm{g} / \mathrm{g}$ dry matter) } \\
\hline & $\mathrm{Cu}$ & $\mathrm{Pb}$ & $\mathrm{Zn}$ & \multirow[b]{2}{*}{ (March) } & \multirow{2}{*}{$\begin{array}{c}\mathrm{Cu} \\
7-15 \\
12(22)\end{array}$} & \multirow{3}{*}{$\begin{array}{c}\mathrm{Pb} \\
53^{-288} \\
12 \mathrm{I}(22) \\
5-70 \\
25(19)\end{array}$} & \multirow{3}{*}{$\begin{array}{c}\mathrm{Zn} \\
43-132 \\
73(22) \\
24-120 \\
39(19)\end{array}$} \\
\hline & $10-204$ & $115-72000$ & $41-1260$ & & & & \\
\hline & $46(42)$ & $3320(42)$ & $247(42)$ & (Aug.) & $\begin{array}{l}5-14 \\
9(19)\end{array}$ & & \\
\hline \multirow[t]{2}{*}{ 'Control' area } & $21-15^{\circ}$ & $75-307$ & $70-284$ & (March) & $\begin{array}{l}\mathrm{r} 4-34 \\
21(7)\end{array}$ & $\begin{array}{c}43-114 \\
68(7)\end{array}$ & $\begin{array}{c}72-123 \\
94(7)\end{array}$ \\
\hline & $48(\mathrm{II})$ & $165(I x)$ & I $28(\mathrm{i} I)$ & (Aug.) & $\begin{array}{c}7-16 \\
11(12)\end{array}$ & $\begin{array}{c}5^{-16} \\
11(12)\end{array}$ & $\begin{array}{l}31-110 \\
52 \text { (12) }\end{array}$ \\
\hline \multirow{2}{*}{$\begin{array}{l}\text { Tamar area } \\
\text { Metal-contaminated } \\
\text { alluvium }\end{array}$} & $35-2000$ & $60-1000$ & $114-1020$ & (Oct.) & $\begin{array}{l}4-20 \\
9(8)\end{array}$ & $\begin{array}{c}7-15 \\
\text { II }(8)\end{array}$ & $\begin{array}{l}26-95 \\
53(8)\end{array}$ \\
\hline & $620(\mathrm{r} 2)$ & $435(12)$ & $368(12)$ & $\begin{array}{l}\text { (May- } \\
\text { June) }\end{array}$ & $\begin{array}{l}7-20 \\
15(5)\end{array}$ & $\begin{array}{l}2-10 \\
7(5)\end{array}$ & $\begin{array}{c}34^{-1} 30 \\
65(5)\end{array}$ \\
\hline 'Control & $\begin{array}{l}36-50 \\
44(5)\end{array}$ & $\begin{array}{l}72-96 \\
85(5)\end{array}$ & $\begin{array}{l}67-180 \\
\text { I } 21(5)\end{array}$ & (Oct.) & $\begin{array}{l}6-10 \\
8(3)\end{array}$ & $\begin{array}{l}6-10 \\
8(3)\end{array}$ & $\begin{array}{l}27-46 \\
39(3)\end{array}$ \\
\hline
\end{tabular}


contamination to only a minor degree (Table 3 ), perhaps as a consequence of the low availability of the metal in the soil or regulatory processes limiting uptake and translocation at the soil-root and root-shoot interfaces. These results are in contrast to the high concentrations of metal measured in both plants and soils sampled downwind from present-day urban and industrial sites (Goodman \& Roberts, 1971). The markedly higher concentrations of $\mathrm{Pb}$ in grass sampled in March compared with August at both contaminated and control sites in the Pennines confirms the seasonal effects for this element previously reported by Mitchell \& Reith (1966).

With the exception of occasional clinical and sometimes fatal cases of $\mathrm{Pb}$ toxicity in grazing cattle and sheep in the Pennine area, there is little evidence to date that these soils contaminated by past industry are affecting animal health or production. On the basis of the above information it is unlikely that the herbage would constitute a hazard to animals. On the other hand, ingested soil may increase the intake of metals by livestock on polluted land, and sub-lethal effects could well affect both production and the composition of animal tissue.

\section{The role of soil ingestion in the soil-(plant)-animal relationship}

Some ro years ago Field \& Purvis (1964) published evidence that, during winter months, ingested soil could amount to as much as $14 \%$ of the sheep's dry matter intake. Subsequently, Healy $(1967,1968)$ has shown that appreciable amounts of soil may be involuntarily ingested by both sheep and cattle under New Zealand farming conditions. It was suggested that soil could be an important source of trace elements in the ruminant diet, particularly of those elements with a relatively high soil: herbage ratio, such as Co. More recently soil ingestion ranging from I to $10 \%$ of the dry matter intake by cattle (140-1400 $\mathrm{g}$ soil/d) has been reported over winter months in south-west England (Thornton, $1974^{b}$ ). These measurements, based on the titanium content of soil and fresh faeces, were made primarily on contaminated land, where soil may contain as much as $2 \mathrm{mg} \mathrm{Cu} / \mathrm{g}$ and herbage only $20 \mu \mathrm{g} / \mathrm{g}$ (Table 3). Under these conditions cattle may possibly ingest up to ten times the amount of $\mathrm{Cu}$ and $\mathrm{Pb}$ (and possibly $\mathrm{As}$ ) in the form of soil compared with that in herbage.

Thus for those elements of low availability to the plant such as $\mathrm{Co}$ and $\mathrm{Cr}$, and on soils heavily contaminated with trace metals, the soil-animal relationship may well over-ride or at any rate complement that of the soil-plant-animal system, though naturally we need to investigate in detail those factors governing availability and absorption within the animal before the importance of this pathway can be fully assessed. In this respect, some $\mathrm{Cu}$ repletion trials recently conducted at the Moredun Research Institute have shown that diets containing $100 \mathrm{~g}$ soil $/ \mathrm{kg}$, irrespective of its Mo content, reduced the availability of $\mathrm{Cu}$ fed as copper sulphate by more than $50 \%$ compared with diets containing no soil (N. F. Suttle, B. J. Alloway $\& \mathrm{I}$. Thornton, unpublished results). This would suggest acclusion of $\mathrm{Cu}$ by soil particles within the alimentary tract. Were this to happen to dietary $\mathrm{Cu}$ from plant material ingested under normal grazing conditions, soil itself might well further complicate the soil-plant-animal relationship at the plant-animal level. 


\section{Human health}

The relationships between man and the trace element status of soils, plants and foodstuffs are to date mainly empirical and outside the scope of this paper. Nonetheless this is a field of increasing concern and in fact led in 1972 to the formation of the Society for Environmental Geochemistry and Health in the United States. In the present context, it is of interest to note that in one of the biogeochemical provinces in Armenia in which bovine molybdenosis has been described, the excess environmental Mo has also been related to a $30 \%$ incidence of endemic gout in man (Kovalsky \& Yarovaya, I966). Similarly, studies in the $\mathrm{Pb}$-contaminated area of the southern Pennines (Fig. I) have shown a significant enhancement of $\mathrm{Pb}$ in blood and hair of 2-3-year-old children in villages with high soil $\mathrm{Pb}$ values compared with nearby controls (Barltrop, Strehlow, Thornton \& Webb, 1974). In the light of present medical evidence, this increased absorption of $\mathrm{Pb}$ in children is thought unlikely to be of biological significance.

\section{Conclusions}

Despite the complex factors affecting the relationships between trace elements in the rock, parent material, soil, plant and animal, problems of deficiency and excess in livestock frequently reflect the chemical composition of soils and the geochemical nature of underlying rock or parent material.

The growing awareness of sub-clinical disorders caused by trace element imbalance has led to the need for regional and national trace element maps. In this respect geochemical reconnaissance surveys based on stream sediment sampling have been successfully used to focus attention on suspect areas where animal health and production may at times be affected. Geochemical maps of England and Wales have been shown to be of particular significance to soil-plant-animal studies in areas of high Mo, multi-element deficiency, and heavy metal contamination.

It is suggested that soil ingestion may play an important role in the trace element nutrition of grazing animals, particularly for those elements of low availability to plants and in areas where soils are heavily contaminated with metals. It thus seems probable that, under certain circumstances at least, the 'total' trace element content of the soil may be of comparable importance to the 'plant-available' content in studies of the over-all soil-plant-animal relationship.

Several examples are cited in the paper from the continuing programme in agriculture of the Applied Geochemistry Research Group, under the over-all direction of Professor J. S. Webb, and supported by the Agricultural Research Council. The geochemical map (Fig. I) was compiled by Dr P. L. Lowenstein as part of a project financed by the Wolfson Foundation.

\section{REFERENCES}

Alderman, G. A. (1968). Rep. Welsh Soils Discuss. Group No. 9, I09.

Alloway, B. J. (1973). F. agric. Sci., Camb. 80, 52 r.

Alloway, B. J. \& Davies, B. E. (1971). F. agric. Sci., Camb. 76, 321 .

Archer, F. C. (1971). Trace Elements in Soils and Crops p. 150. London: H.M. Stationery Office. 
Barltrop, D., Strehlow, C. D., Thornton, I. \& Webb, J. S. (1974). Environ. Hlth 82, 75.

Brogan, J. C., Fleming, G. A. \& Byrne, J. E. (1973). Ir. F. agric. Res, 12, 7 I.

Department of Scientific and Industrial Research (1967). Soil Bureau Atlas. Wellington, New Zealand: Department of Scientific and Industrial Research.

Dye, W. B. \& O'Hara, J. L. (1959). Bull. Nev, agric, Exp. Stn no. 208.

Ferguson, W. S., Lewis, A. H. \& Watson, S. J. (1943). F. agric. Sci, Camb. 33, 44.

Field, A. C. \& Purvis, D. (rg64). Proc. Nutr, Soc. 23, xxiv.

Fleming, G. A. (1965). Outl. Agric. 4, 270.

Goodman, G. T. \& Roberts, T. M. (1971). Nature, Lond. 231, 287.

Havre, G. N. (1970). In Trace Element Metabolism in Animals p. 117 [C. F. Mills, editor]. Edinburgh and London: Livingstone.

Healy, W. B. (1967). Proc, N.Z. Soc. Anim. Prod. 27, 109.

Healy, W. B. (1968). N.Z. 7 l agric. Res. II, 487.

Howarth, R. J. (197I). Math. Geol. 3, 95.

Kiely, P. V. \& Fleming, G. A. (1969). Proc. R. Ir. Acad. B 68, I.

Kovalsky, V. V. (1970). In Trace Element Metabolism in Animals p. 385 [C. F. Mills, editor]. Edinburgh and London: Livingstone.

Kovalsky, V. V. \& Yarovaya, G. A. (1966). Agrokhimija 8, 68.

Kubota, J. (1964). Proc. Soil Sci. Soc. Am. 28, 246.

Kubota, J. \& Allaway, W. H. (1972). In Micromutrients in Agriculture p. 525 [J. J. Mortredt, editor]. Madison, Wisconsin: Soil Science Society of America,

Le Riche, H. H. (1959). Y. Soil Sci. ro, I33.

Lewis, A. H. (1943). F. agric. Sci., Camb. 33, 52.

Mitchell, R. L. (1965). In Trace Elements in Soils p. 320 [F. E. Bear, editor]. New York and London: Reinhold.

Mitchell, R. L. \& Reith, J. W. S. (1966). 7. Sci. Fd Agric. 17, 437.

Patterson, J. B. E. (1938). Emp. F. exp. Agric. 6, 262.

Purvis, D. (1972). Environ. Pollut. 3, 17.

Russell, F. C. \& Duncan, D. L. (1956). Minerals in Pasture: Deficiencies and Excesses in Relation to Animal Health 2nd ed. Farnham Royal, Bucks.: Commonwealth Agricultural Bureaux.

Swaine, D. J. \& Mitchell, R. L. (rg6o). F. Soil. Sci. Ir, 347.

Thomson, I., Thornton, I. \& Webb, J. S. (1972). F. Sci. Fd Agric. 23, 878

Thornton, I, (1974a). Proc. Minerals in the Environment Symp. London 1974 (In the Press.)

Thornton, I. (1974b). In Trace Element Metabolism in Animals [W. G. Hoekstra, J. W. Suttie, H. E. Ganther and W. Mertz, editors]. Baltimore, Maryland: University Park Press.

Thornton, I., Kershaw, G. F. \& Davies, M. K. (1972a). F. agric. Sci., Camb. 78, 157.

Thornton, I., Kershaw, G. F. \& Davies, M. K. (1972b). F. agric. Sci., Camb. 78, 165.

Thornton, I. \& Webb, J. S. (1970). In Trace Element Metabolism in Animals p. 397 [C. F. Mills, editor]. Edinburgh and London: Livingstone.

Thornton, I. \& Webb, J. S. (1973). In Trace Substances in Environmental Health Vol. 2, p. 89 [D. D. Hemphill, editor]. Columbia, Missouri: University of Missouri.

Underwood, E. J. (1971). Trace Elements in Human and Animal Nutrition 3 rd ed. New York and London: Academic Press.

US Geological Survey (1969-73). Geochemical Survey of Missouri, Open-file Reports. Denver, Colorado: US Geological Survey.

Van der Merwe, F. J. (1959). S. Afr. F. agric. Sci. 2, I4r.

Walsh, T., Neenan, M. \& O'Moore, L. B. (1952). 7. Dep. Agric. Repub. Ire. 48, 3.

Webb, J. S. (1964). New Scient. 23, 504.

Webb, J. S. \& Atkinson, W. J. (1965). Nature, Lond. 208, 1056.

Webb, J. S., Lowenstein, P. L., Howarth, R. J., Nichol, I. \& Foster, R. (1973). Provisional Geochemical Atlas of Northern Ireland. London: Applied Geochemistry Research Group.

Webb, J. S., Thornton, I. \& Fletcher, K. (1968). Nature, Land. 217, I010. 